\title{
Horizon scanning rural crime in England
}

by Smith, K. and Byrne, R.

Copyright, Publisher and Additional Information: This is the author accepted manuscript. The final published version (version of record) is available online via Cambridge University Press

Please refer to any applicable terms of use of the publisher.

DOI: https://doi.org/10.1057/s41300-019-00073-7

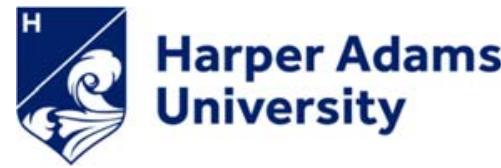

Smith, K. and Byrne, R. 2019. Horizon scanning rural crime in England. Crime Prevention and Community Safety. 


\title{
Horizon Scanning Rural Crime in England
}

Kreseda Smith ${ }^{\mathrm{a}}$ and Richard Byrne ${ }^{\mathrm{a}}$

a'Land, Farm and Agribusiness Management Department, Harper Adams University, Shropshire, UK

Correspondence: Kreseda Smith, Land, Farm and Agribusiness Management Department, Harper Adams University, Newport, Shropshire, TF10 8NB, UK. E-mail: kresedasmith@harper-adams.ac.uk

\begin{abstract}
Despite increasing levels of research addressing rural crime, this field of academia remains under-researched across the world, and the impact crime has upon rural communities continues to be underestimated. In particular, levels of rural crime research in England pale in comparison with the amount of research that is taking place in other developed countries such as the United States and Australia. This paper provides a horizon scan of emerging rural crime threats in England, and considers how this methodology could help practitioners in the UK and other countries.

This study illustrates that there are a number of emerging crime trends affecting English rural communities. By identifying these evolving issues, this paper contributes to future research and guidance within the English rural crime arena.
\end{abstract}

Keywords

Rural; crime; challenge; OCGs; emerging threats

\section{Introduction}

The predominantly urban population of England tends to view rural crime as a non-issue; urban crime is visible (Smith, 2010), and therefore resources should be focused there. 
Rural policing and crime reduction policies in England have never matched those of urban environments due to the lower reported crime levels and perceived lack of need (Gilling and Pierpoint, 1999; Yarwood, 2001). However, by the turn of the century, rural researchers were starting to consider the effects of being a victim of crime, and victims attitudes towards the criminal justice system.

Rural criminological research is mainly focused in the United States (Donnermeyer, 2007; Donnermeyer \& DeKeseredy, 2013; Weisheit, Falcone \& Wells, 2005) and Australia (Barclay \& Donnermeyer, 2002; Hogg \& Carrington, 2006; Jobes, 2002), with English rural crime research increasing in recent years (Aust \& Simmons, 2002; Mawby, 2007; Smith \& Byrne, 2017). This recent increase in rural crime research in England is imperative to assess the driving forces behind this phenomenon.

It is a common misconception that rural areas are a crime free idyll. In reality, rural crime in England is evolving rapidly, making crime prevention increasingly difficult. While tractors, livestock, and agricultural machinery are still being stolen, there are now signs of an inexorable rise in organised crime gangs targeting rural communities. Indeed, the link between organised crime and rural crime has already been acknowledged in other European countries such as Ireland (Moore-Walsh \& Walsh, 2017) and Italy (BBC, 2011).

Such rapid changes create problems as the community policing models currently employed by police forces across England seem slow to react to changing criminal trends (Loveday, 2017). Budget cuts in an age of austerity imposed by the current UK government mean police forces face an inability to adapt, as organised crime and approaches to tackling it become more complex (HMIC, 2017). Moreover, budget cuts further hinder rural forces who face a legacy of lower funding levels than their 
metropolitan counterparts. With these demands on police budgets expected to continue, the question is whether rural communities need to become their own guardians.

To move the English rural crime debate forward, this paper undertakes a horizon scan provides a snapshot of the emerging issues faced by English rural communities. This is intended to drive research and strategic plans aimed at directly tackling problems such as Organised Crime Gangs (OCGs) and emerging crime trends that are the reality of crime in rural England.

The wider use of horizon scanning within rural criminology would enable academia and practitioners including the police, insurers, and policy makers, to assess potential future developments as well as persistent problems. This would allow key stakeholders to better understand future uncertainties and how rural crime may develop over the short to medium term. Such an approach may lead to a more proactive response from key actors. Moreover, this may ultimately increase confidence levels among rural communities, who could see that rural crime is being taken seriously by key practitioners.

\section{Horizon Scanning}

Horizon scanning is a tool used to aid strategic decision-making at a regional or national level. An examination of risk, uncertainty and emerging trends identify future issues that need to be addressed to mitigate their impact (Garnett et al, 2016; Sutherland et al, 2010). Horizon scanning is an increasingly adopted technique to systematically examine threats and opportunities across a range of areas (OECD, 2018). Based on desk research, it uses various sources, including literature drawn from both peer reviewed and grey literature to form opinion on what issues will remain constant, increase, or diminish, and what new 
factors come into play in the near or distant future. Horizon scanning is not about making predictions, but seeking to identify trends (Gov.uk, 2018). Horizon scanning is widely used by the UK government to inform policy and to establish whether it is robust enough to meet future needs.

Horizon scanning has been widely adopted by various organisations worldwide. Examples include the UK government (House of Commons, 2014), and international academic researchers identifying emerging issues for global conservation (Sutherland et al, 2017). The UN FAO has employed horizon scanning to identify emerging issues in food safety (FAO, 2014), and in the United States the Agency for Healthcare Research and Quality employed this methodology to identify emerging healthcare technologies and innovations (AHRQ, 2016).

This research carried out a horizon scan of emerging rural crime trends in England. Relevant media, police, and industry reports from the internet were retrieved to identify potential future issues that have yet to be fully considered within both academic and nonacademic research. It will show how horizon scanning can be used to develop rural criminology research by identifying emerging crime trends, as well as those issues historically overlooked by scholars. It will also support the use of horizon scanning as a methodology to explore emerging rural crime trends in countries worldwide. This includes countries that already have an established rural crime research base, but more importantly those countries to which rural crime is a new area of scholarship.

\section{Emerging Crime Trends}


As with crime in general, market forces drive rural crime. Supply and demand often dictates what is targeted by criminals. This has led to a number of emerging crime trends in England in the last year or so. As a result, criminals have become increasingly adaptable to these market forces. Despite the lack of official data or academic research addressing these emerging rural crime trends, patterns are nonetheless seen mainly in news reports.

\section{Poaching and Hare Coursing}

Poaching is classified as an offence under the Deer Act 1991, the Game Act 1831 and the Night Poaching Act 1828 in England and Wales. This makes it an offence for a person to trespass onto land and take or destroy game birds (including pheasant and grouse), deer, and hares or rabbits (BASC, 2013). Hare coursing was made illegal in 2004 with the Hunting Act making it an offence for a person to use a dog to chase, catch and kill hares (Lincolnshire Police, 2016). However, in reality, it is often the case that it is difficult to prove offences of poaching or hare coursing. As a result, the police tend to rely on other legislation, such as the Theft Act 1968 or the Road Traffic Act 1988 to target the perpetrators. Poaching and hare coursing tend to be considered as crimes of the past. However, in reality, rural police forces are increasingly being confronted by these crimes and the offenders.

In a bid to tackle poaching, the National Wildlife Crime Unit is working in partnership with various country organisations and the police on a strategic response to the problem. Project Poacher provides advice and support for law enforcers, and a free mobile phone app for the public to report incidences of poaching (The Deer Initiative, 2017). In 
addition, the National Police Chiefs Council announced the launch of national Rural Crime and Wildlife Crime Strategies in July 2018. Various police forces across England and Wales are conducting operations to tackle hare coursing within their area. A prominent example is that of Operation Galileo established by Lincolnshire Police in 2012, which a small number of other forces across the east of England have adopted. However, there does not seem to be a widespread, coherent approach to tackling these offences, despite poaching and hare coursing being found in many part of England.

Many of those who take part in hare coursing are brazen. They video the chase, and run large betting schemes based on the outcome of the chase (Humberside Police, 2015), either by way of bets on the videos posted on YouTube, or live streaming the chase on media such as Facebook Live $^{\mathrm{TM}}$ or Periscope $\mathrm{TM}^{\mathrm{TM}}$ and taking live bets. Moreover, perpetrators are becoming increasingly violent if approached in a bid to protect their moneymaking enterprises. This is increasingly being reported in the press (BBC, 2017a, b) and by the police (Lincolnshire Police, 2017).

\section{Agrochemical Theft and Counterfeiting}

A particularly noticeable trend is the theft and counterfeiting of agrochemicals and the impact this has upon the agricultural sector in England. Whilst the theft of agrochemicals has historically been rare in England it cannot be safely ignored (Sambrook, 2013). However, there have been a growing number of reports of agrochemicals being stolen, highlighting this as a growing problem. There are examples including $£ 20,000$ of agrochemicals being stolen in one raid (Farming UK, 2014). This level of theft raises the question of why these chemicals are being stolen; it is likely this is feeding illegal drug 
production. A common fertiliser, Anhydrous Ammonia, is often directly associated with the production of methamphetamine (Minnesota Department of Agriculture, undated). However, this chemical poses a significant risk to human health, and an explosive risk (CDC, 2011). Furthermore, agrochemicals per se can present a very substantial health risk to the wider community.

One example involved the report of the theft of the pesticide Phostoxin on Merseyside in England in 2014 (BBC, 2014a). The main constituent is the chemical Aluminium Phosphide, which in pellet form is used to control rabbits, rats and moles in the UK (Rentokil, undated). However, when Aluminium Phosphide reacts with moisture it produces phosphine gas which is highly toxic (Extoxnet, 1996), extremely flammable and explosive (Assem \& Takamiya, 2007). Mild exposure to phosphine gas can lead to symptoms such as nausea and fatigue, with high-level exposure leading to coma or death (Bond, 1989). However, the level at which humans can detect the odour of phosphine does not provide sufficient warning of dangerous concentrations (CDC, 2015). The vapour is heavier than air, will collect to hazardous levels and stay in poorly ventilated or confined areas (CDC, 2015), such as barns or stores.

Counterfeit agrochemicals are also a growing problem in England and across Europe, and is expected to increase with the fall in Sterling. Worldwide, counterfeit crop protection products are a major problem - this illegal industry is believed to be worth around $\$ 5.8$ Billion a year (Sambrook, 2013). The European Crop Protection Association (ECPA) estimates that in Europe at any one time up to $10 \%$ of pesticides on the open market are counterfeit (ECPA, 2012). Europol \& The Office for Harmonization in the Internal Market (2012) reported that, despite being among the most regulated products in the world, increasing amounts of stolen and counterfeit pesticides are finding their way into 
European farming systems leading to ruined crops, adulterated food chains, and a wider public health issue.

It is essential that the theft and counterfeiting of agrochemicals is considered and better understood, as it is likely to be seen as a key indicator of the development of organised crime in rural areas in the future. These offences may be indicative of wider crime offences, such as the prevalence of drug production within rural areas of the UK. Moreover, with the exit of the UK from the European Union, there may be wider issues relating to food chain security to consider. Such issues may arise because of prices of agrochemicals rising post-Brexit due to import duties, leading to farmers seeking out

cheaper alternatives. Practitioners should use horizon scanning to identify possible future uncertainties and market forces at work within the wider rural crime arena to address potential future problems as early as possible.

\section{Theft of Commercial Solar Panels}

Another emerging trend particularly noticeable during 2015, but still ongoing in England, is the theft of commercial scale Photovoltaic (PV) panels from solar farms. This is indicative of the adaptability of organised criminal entrepreneurs to supply and demand. There have been increasing numbers of commercial solar farms established in rural areas of the UK. In 2014, there were 200 solar farms in the UK (The Guardian, 2014). In the first quarter of 2017, it was estimated that 118 were being installed (Colville, 2017). This increase was driven by the need to meet an EU renewable energy target of sourcing $15 \%$ of its energy from renewable sources by 2020 (Burke, 2015). Despite stringent planning permission (DCLG, 2015), many of these ground-mounted solar farms are being created, 
varying in size from one to one hundred acres (Burke, 2015), creating new targets for the criminal fraternity.

NFU Mutual (the UK equivalent of the American Agricultural Insurance Company (AAIC)) in 2015 reported that solar panel theft costed UK farmers around $£ 50,000$ during 2014, with claims in the first quarter of 2015 having risen sharply (AMBA Defence, 2015).

These PV panels are large and not something that would be considered as easily disposable. Despite this, there are reports of large numbers of panels being stolen in a short period of time (Stratford-on-Avon Standard, 2017). Each panel is, on average, 2 metre square, and weighs approximately 20kg (44lbs) (BrightStar Solar, 2014), and has little or no scrap value (Farmers Weekly, 2015). The ability to dismantle and remove a large number of panels in such a short space of time would indicate the involvement of organised criminals. In many cases, these stolen panels end up for sale on online auctions such as eBay (Galbraith, 2008; Anon, 2013); however, it is asserted that many of these panels may well end up in less developed countries where regulations surrounding such commodities are much lighter or non-existent (Lawson, 2012) making the disposal of the stolen panels much easier for criminals.

\section{Heritage Crime and Illegal Off-Roading}

Historically, lead roofing stolen from churches, gates, copper wiring from farms, and metal from gravestones and war memorials (Price et al., 2014) would be taken to a scrap metal dealer and disposed of quickly and easily. There would be no paper trail, allowing criminals to avoid detection by using false identities. The introduction of the Scrap Metal 
Dealers Act in 2013 at the height of incidences of metal theft in England was meant to target and reduce the numbers of scrap metal dealers who deal in cash. However, a review of the legislation carried out by the British Metals Recycling Association (BMRA) concluded that the introduction of the Scrap Metal Dealers Act did act to reduce the levels of metal thefts. However, it was probably an increase in police enforcement combined with the global reduction in metal prices that had a far greater impact (BMRA, 2017).

Despite this, these thefts continue to cause concern amongst rural communities and impact upon the victims (Coombes et al, 2012). In addition, heritage crime also includes the recent trend in England of paving and stone walling (Figure 1) being targeted, due to increased prices of quality heritage stone, such as York stone, as reported in the UK Broadsheet press (Telegraph, 2015). These items seem to be targeted as they frequently have a quick means of disposal, often with an unsuspecting gardener buying stone for their own private landscaping.

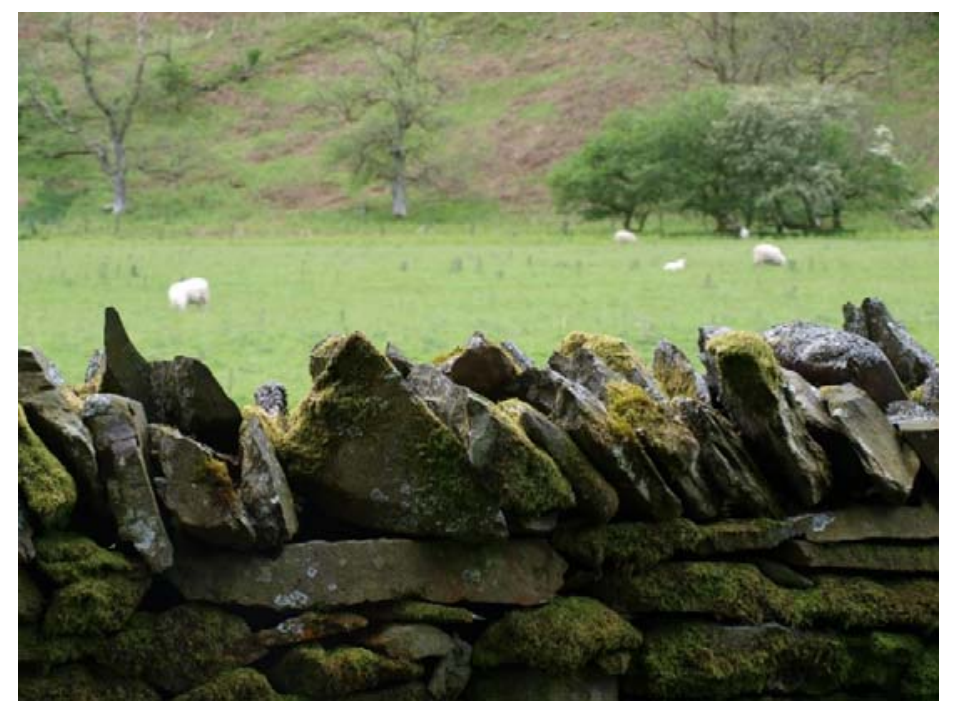

Figure 1: Example of stone-walling in England and Wales (Source: Authors Own)

As a result, the Sentencing Council in the United Kingdom published new guidelines, which came into effect on $1^{\text {st }}$ February 2016 (Sentencing Council, 2015a). These new 
guidelines enable judges to consider the impact such crimes have on the victims other than the immediate financial losses they suffer. This brings heritage theft sentencing in line with other theft categories, with a maximum sentence of seven years' imprisonment with the option of extending this where there are multiple crimes or significant contributing factors (Sentencing Council, 2015a).

These guidelines were warmly welcomed by the National Policing and Crime Advisor for Historic England, Mark Harrison. He commented that the "impact of theft on our historic sites and buildings has far-reaching consequences over and above the financial cost of what has been stolen" (Sentencing Council, 2015b).

Across England there are large numbers of Public Rights of Way (PRoW) designated and protected by statutes, including the Rights of Way Act 1990, the Countryside and Rights of Way Act 2000, and the Natural Environment and Rural Communities Act 2006. These PRoWs are categorised as footpaths, bridleways, byways, and byways open to all traffic. Figure 2 below illustrates the users legally allowed to use each of these categories of PRoWs.

\begin{tabular}{|l|l|}
\hline $\begin{array}{l}\text { PRoW Type } \\
\text { Total: 188,700 } \mathbf{k m}\end{array}$ & Permitted Access \\
\hline $\begin{array}{l}\text { Footpath } \\
\mathbf{1 4 6 , 6 0 0 k m}\end{array}$ & On Foot only \\
\hline $\begin{array}{l}\text { Bridleway } \\
\mathbf{3 2 , 4 0 0 k m}\end{array}$ & $\begin{array}{l}\text { On foot, horseback and on a pedal cycle (including mountain } \\
\text { bikes) }\end{array}$ \\
\hline $\begin{array}{l}\text { Restricted Byway } \\
\mathbf{6 , 0 0 0 k m}\end{array}$ & $\begin{array}{l}\text { On foot, horseback and with non-mechanically propelled } \\
\text { vehicles (such as pedal cycles and horsedrawn vehicles) }\end{array}$ \\
\hline $\begin{array}{l}\text { Byway Open to All } \\
\text { Traffic (BOAT) } \\
\text { 3,700km }\end{array}$ & $\begin{array}{l}\text { On foot, horseback or pedal cycle and by wheeled vehicles of } \\
\text { all kinds, including horsedrawn vehicles, but which is used by } \\
\text { the public mainly for walking or for riding. }\end{array}$ \\
\hline
\end{tabular}

Figure 2: Definitions of Public Rights of Way (Source: Natural England, 2008; Highways England, 2015) 
As can be seen from Figure 2, motorised vehicles are only permitted on Byways Open to All Traffic. However, there have been increased incidents of off-road vehicles, trail bikes, and quad bikes being illegally driven over protected countryside and farmland causing upheaval and surface erosion and damaging delicate ecosystems and archaeology (Ministry of Defence, 2015). These illegal actions have taken place on footpaths, bridle paths, restricted byways, and common ground (BBC, 2014b). However, they have also been seen on protected countryside, such as Sites of Special Scientific Interest (SSSIs), Scheduled Ancient Monuments, Special Areas of Conservation, and Special Protection Areas, which are protected by UK and European law (Natural Resources Wales, 2014). A number of attempts have been made to tackle illegal off-roading, with opportunities for potential prosecution under statutory instruments such as the Wildlife and Countryside Act 1981, as amended by the Countryside and Rights of Way Act 2000. The latter states that it is "an offence...intentionally or recklessly damage any of the flora, fauna, geological or physiographical features by reason of which land is of special interest". However, it is difficult to see how these statutory measures and guidelines will reduce incidences of heritage crime, with reduced resources for police and other key stakeholders enabling identification and subsequent prosecution of offenders.

\section{Cybercrime and Drones}

Rural communities are having to take steps to protect themselves from those who choose to use this technology for nefarious purposes, with the 2015 NFU Mutual Rural Crime Survey reported that $63 \%$ of their clients were concerned about cybercrime (NFU Mutual, 2015). Historically online crimes were committed by individual criminals working alone; 
there is now increasing evidence that cybercrime is being committed by criminal networks that extend across international borders such is the nature of the internet (RSM UK, 2015).

Rural and farming communities in England are carrying out their day to day business remotely and are increasingly using autonomous technology in farming equipment particularly tractors (Rehman et al, 2016). Online security company McAfee warned in 2011 that emerging threats include "online transaction and applications...but also industrial control systems, robotics, home automation, and on-board systems". This poses a potential hazard to farmers submitting business returns online, and receiving farming payments direct into their bank account. Moreover, this warning from McAfee could raise issues relating to the ever-increasing automation of tractors, specifically whether these on-board systems could be hacked thus assisting in the theft of such equipment.

The rise in popularity of drones or Unmanned Aerial Vehicles (UAVs) in England over the last year or so, has impacted both positively and negatively on farmers. UAVs enable whole field mapping of factors such as crop conditions, soil properties, water content, and weed distribution (Torres-Sanchez et al, 2013). In addition, they seem to be an attractive tool for livestock farmers. They allow the farmer to herd sheep (The Times, 2015), carry out headcounts quicker than by hand (Alimuzzaman, 2015), and enable farmers to easily identify livestock health issues and mother-child bonding (Drankhan, 2015).

However, rural communities are also exposed to the darker uses of UAVs. Criminals are using technology to identify targets without drawing suspicion to themselves. They can remain out of site while they establish what a farmer owns, and any potential lapses in security they could make use of at a later date (Plymouth Herald, 2016). This poses 
additional security issues for the farmer and the general rural community when trying to protect their property from these criminals.

Criminals are also using this technology to identify potential targets of heritage crime. Reports have seen organised criminals using UAVs and Google Earth to survey church roofs and remove tonnes of metal worth thousands of pounds (The Independent, 2015).

\section{Modern Slavery}

Modern slavery within UK agriculture is an issue that remains hidden from the general public, but is an increasing phenomenon (HM Government, 2014; Anderson and Rogaly, 2005). Modern slavery is rooted in organised crime both nationally and internationally, creating huge income for organised crime gangs; only drugs and arms smuggling rank higher in the list of criminal activity (CRS, 2015).

Many victims of trafficking in the UK end up being subjected to forced labour as 'gardeners' in rural cannabis factories, and also within the agricultural sector (Byrne \& Smith, 2016). Many of those forced into tending cannabis farms in rural England are southeast Asian - Vietnamese or Filipino. They are trafficked to England with a promise of legitimate employment, to have their passports confiscated and forced to work for little or no money (Byrne \& Smith, ibid). These victims may also be subjected to debt bondage, where the trafficker forces the victim to work to pay off hugely inflated costs of travel arrangements, accommodation, food, a work arrangement fee, and miscellaneous trafficker fees (CEOP, 2011).

Open borders within Europe has meant an influx of workers to England from Eastern Europe, particularly, Poland and Lithuania. While many of them manage to find gainful 
employment, a large minority become the target of illegal gangmasters and find themselves working in, for example the horticultural sector, working long hours for little pay, forced to live in appalling conditions (BBC, 2014c). The role of Brexit is yet to be seen, but it is anticipated more people will be trafficked into the UK before borders close, to then be subjected to slavery and moved around the UK as required.

\section{Organised Crime Gangs and the Internationalisation of Rural Crime in England}

Rural England is no longer the domain of the 'gentleman poacher' (Quinn, 2015). They are increasingly becoming the target of Organised Crime Gangs (OCGs) who see these areas as soft targets because of historic low levels of crime prevention (Wiles and Costello, 2000). Farms seem to be falling prey to organised criminals who are travelling across local, regional and national borders to locate items on a shopping list (Cann, 2014; Local Government Association, 2015) that are then stolen to order. Once they locate a suitable target, these motivated offenders will surveil the farm over a period of time to identify the presence of a capable guardian (Cohen and Felson, 1979). These criminals are stealing to order as a small part of a much larger, possibly multinational, crime syndicate which is likely linked to other crimes such as slavery/human trafficking or drug production and/or trafficking (Wall and Chistyakova, 2015).

Rural thefts are often items that are easily removed and disposed of, such as quad bikes/all-terrain vehicles. However, levels of large-scale livestock rustling are also increasing across England, showing a high level of organisation and forward planning. Livestock with low levels of security need to be identified, transport for the livestock and some way of getting them aboard the transport, such as a sheepdog, is needed. Offenders 
must have some way to dispose of the livestock, via an illegal abattoir in many cases, followed by a secured onward market for the butchered meat.

The increasing evidence of rural areas being targeted by OCGs, leads to a conclusion that English rural crime is becoming increasingly internationalised. Tractors are being stolen to order, and quickly shipped across to continental Europe for onward transporting to Eastern Europe, the Middle East, and North Africa among other destinations (Hardy et al, 2007). There is evidence that older tractors also have a value, and tend to be stolen, dismantled, and shipped to developing countries to meet the need for parts (Smith and McElwee, 2015). It is suggested that these items being transported across national borders are used as payment for people, drugs and arms for the return journey of the transporter, but there is little official evidence of this being the case.

\section{Conclusions}

In conclusion, it is evident that emerging threats are affecting rural England in a way that has never been seen before, possibly threatening the prosperity of these rural communities. Criminals are driven by market forces in identifying their targets, and as a result it is unlikely that the police or the communities could plan crime prevention measures that would dissuade a determined criminal. In light of such emerging threats, it is likely that various organisations will have to establish, or improve, co-operative crime prevention actions to address these increasing issues.

Coupled with the fact that rural England is facing numerous emerging threats, is the indication that OCGs are increasingly targeting the English countryside. This brings with it new problems that the residents and workers of rural England must face and tackle, but 
also added pressure for the police forces of England and Wales and policy-makers to address adequately.

In conclusion, this paper has shown how the use of horizon scanning can aid in the identification and analysis of emerging rural crime trends in England. It is recommended that the use of horizon scanning and wider futures research methodologies can be successfully applied in the pursuit of the advancement of rural criminological scholarship. Even in those countries where rural crime research has well-established literature, horizon scanning may provide the key to teasing out new dimensions of rural crime issues pertinent to any country in the world. Such methodologies are not country-specific, and so could easily be translated to other countries to add to the toolbox of both rural crime researchers and practitioners worldwide. The process of conducting desk-based research can be specific to a particular country based on its needs. Internet searches can be conducted based on key local search criteria, and access to local or national documents and literature can be obtained. While horizon scanning seems to be used predominantly in 'western' countries, it is recommended that rural crime practitioners and researchers consider this methodology to widen their knowledge and understanding of the future trajectory of rural crime, wherever they are in the world.

The key challenge for practitioners highlighted by this work, is the diverse range of crimes and thus investigative skills that are now, and increasingly likely to be, required to deal with future rural crime incidents. This has profound implications not only for resources, but for training of police and support staff. The greater internationalisation of rural crime, and the greater involvement of OCGs, will require a change in the policy dealing with rural crime. 
At present much rural crime is seen as property crime which is largely covered by insurance claims. However, recognising the involvement of OCGs should alert policy makers to the issue that these geographically dispersed, and often high value, crimes have the potential to be part of a growing crime-terror nexus as noted by Makarenko \& Mesquita (2014) and Gaub \& Lisiecka (2014). The view of petty crime may also need to be challenged, as what may be perceived as small, inconsequential thefts of lower value items may be part of a larger, organised, operation collecting and collating these items for re-sale.

Additionally, it is clear that the nature of rural crime such as stock theft, which often leads to illegal abattoirs and food fraud, will involve complex chains of intermediaries meaning greater need for cooperation between police, trading standards, and environmental health officers, among other practitioners. While the 2013 Horse Meat Scandal ${ }^{1}$ alerted the public to the issue, it is clear that in the UK post-austerity, cuts to policing, Food Standards Agency, and environmental health services has left a system incapable of fully dealing with such an issue. This then has further consequences for both consumers, the agricultural industry, and the wider trust in UK food products.

\section{References}

AHRQ (2016) Evaluation of the AHRQ Healthcare Horizon Scanning System. Retrieved 06/09/2017 from https://ahrq-ehc-application.s3.amazonaws.com/media/pdf/horizonscan research.pdf

Alimuzzaman, M.D. (2015). Agricultural Drone. Retrieved 21/04/2016 from https://www.researchgate.net/publication/280093427_Agricultural_Drone._DOI: 10.13140/rg.2.1.1146.2247

\footnotetext{
${ }^{1}$ The 2013 Horse Meat Scandal, or HorseGate as it came to be known, was a European-wide illegal activity whereby processed foods advertised as containing beef where found to contain undeclared or improperly declared horse meat or in some cases pork.
} 
AMBA Defence (2015). Is Solar Panel Theft a Growing Security Issue? Retrieved 18/01/20/16 from https://www.amba-defence.com/defence-blog/solar-panel-theftgrowing-security-issue

Anderson, B. \& Rogaly, B. (2005). Forced Labour and Migration to the UK. Retrieved 18/02/2016 from https://www.compas.ox.ac.uk/2007/pr-2007-forced labour tuc/

Anon. (2013). Growing Black Market for Solar Panels. Retrieved 18/01/2016 from http://www.sustainablebusiness.com/index.cfm/go/news.display/id/24945

Assem, L. \& Takamiya, M. (2007) Phosphine Information Sheet for the Health Protection Agency. Retrieved 22/04/2016 from

https://www.gov.uk/government/uploads/system/uploads/attachment_data/file/317737/P hosphine_properties_incident_management_toxicology.pdf

Aust, R. \& Simmons, J. (2002). Rural Crime: England and Wales, 01/02. London: Home Office.

Barclay, E. \& Donnermeyer, J.F. (2002). Property Crime and Crime Prevention on Farms in Australia. Crime Prevention and Community Safety: An International Journal, 4; 4761. DOI:10.1057/palgrave.cpcs.8140169.

BASC (2013) Poaching of Game, Deer and Fish. Retrieved 09/03/2017 from https://basc.org.uk/game-and-gamekeeping/rural-crime/

BBC (2011) Italy to probe mafia's 'stranglehold on tomato trade'. Retrieved 26/04/2017 from http://www.bbc.co.uk/news/world-europe-12388326

BBC (2014a) Dangerous' pesticide stolen in Bromborough burglary. Retrieved 18/01/2016 from http://www.bbc.co.uk/news/uk-england-merseyside-30095932

BBC (2014b). Police target illegal off-roaders. Retrieved 18/01/2016 from http://www.bbc.co.uk/news/uk-wales-mid-wales-28558864

BBC (2014c). Gangmasters Licensing Authority to appeal 'shocking' sentence. Retrieved 27/04/2016 from http://www.bbc.co.uk/uk-northern-ireland-29547874

BBC (2017a) Hare Courses 'becoming increasingly violent'. Retrieved 09/03/2017 from http://www.bbc.co.uk/news/uk-england-lincolnshire-38530950.

BBC (2017b) Specials brought in to tackle hare coursing in 'Wild West' county. Retrieved 09/03/2017 from http://www.bbc.co.uk/news/uk-england-lincolnshire$\underline{38704282}$

BMRA (2017) BMRA response to the Home Office review of The Scrap Metal Dealers Act 2013, dated December 2016. Retrieved 08/03/2017 from https://www.recyclemetals.org/asset/EE78732A-284E-4CE3-93462B805C8B6C2B/ 
Bond, E.J. (1989) Manual of fumigation for insect control. FAO Report 54. Retrieved 22/04/2016 from www.fao.org/docrep/x5042e/x5042E00.htm\#Phosphine

BrightStar Solar (2014). Common Sizes of Solar Panels. Retrieved 25/04/2016 from http://brightstarsolar.net/2014/02/common-sizes-of-solar-panels/

Burke, M. (2015). Solar Farms: Funding, planning and impacts. House of Commons Library Briefing Paper No. 07434. Retrieved 16/12/2015 from http://researchbriefings.parliament.uk/ResearchBriefing/Summary/CBP-7434

Byrne, R. \& Smith, K. (2016). Modern Slavery in Agriculture. In J.F. Donnermeyer (Ed.) The Routledge International Handbook of Rural Criminology. Abingdon, Oxfordshire: Routledge

Cann, R. (2014). Round 'em up. Police Monthly, November 2014, 16-17. Retrieved 25/04/2016 from

http://www.police.nsw.gov.au/_data/assets/pdf_file/0004/318685/PM_Nov14_p1617.pdf

CDC (2011). Ammonia Solution (UN 3318); Ammonia, Anhydrous (UN 1005): Lung Damaging Agent. $\quad$ Retrieved 22/01/2016 from http://www.cdc.gov/niosh/ershdb/emergencyresponsecard_29750013.html

CDC (2015). Phosphine: Lung Damaging Agent. Retrieved 22/04/2016 from www.cdc.gov/niosh/ershdb/emergencyresponsecard 29750035.html

CEOP (2011). The trafficking of women and children from Vietnam. London: CEOP

Cohen, L. E. and Felson, M. (1979). Social change and crime rate trends: A routine activity approach. American Sociological Review, 44; 588-608.

Colville, F (2017) Exclusive: UK installed 640MW of solar in Q1 2017. Retrieved $13 / 10 / 2017$ from

https://www.solarpowerportal.co.uk/news/exclusive uk installed 640mw of solar in q1 2017

Coombes, M., Bradley, D., Grove, L., Thomas, S. \& Young, C. (2012). The Extent of Crime and Anti-Social Behaviour Affecting Designated Heritage Assets. Report prepared for English Heritage. Retrieved 12/03/2016 from http://www.englishheritage.org.uk/content/imported-docs/p-t/researchpaper.pdf

Countryside and Rights of Way Act (2000) Retrieved 08/03/2017 from http://www.legislation.gov.uk/ukpga/1990/24/contents

CRS (2015) Catholic Relief Services - Human trafficking in Albania. Retrieved 25/03/2016 from http:/www.crs.org/albania/human-trafficking-in-albania-hiding-inplain-sight/ 
DCLG (2015). Planning Practice Guidance: Renewable and low carbon energy. Particular planning considerations for hydropower, active solar technology, solar farms, and wind turbines. Retrieved 15/12/2015 from http://planningguidance.communities.gov.uk/blog/guidance/renewable-and-low-carbonenergy/particular-planning-considerations-for-hydorpower-active-solar-technologysolar-farms-and-wind-turbines/

Deer Act (1991) Retrieved 09/03/2017 from

http://www.legislation.gov.uk/ukpga/1991/54/contents

Donnermeyer, J.F. (2007) Rural Crime: Roots and Restoration. International Journal of Rural Crime, $1 ; 2-20$

Donnermeyer, J.F. \& DeKeseredy, W.S. (2013) Rural Criminology. London: Routledge

Drankhan, H. (2015). UAVs bring new perspective to precision agriculture. Retrieved 26/04/2016 from http://www.progressivedairy.com/topics/barns-equipment/uavs-bringnew-perspective-to-precision-agriculture

ECPA (2012). Stopping Counterfeit and Illegal Pesticides (Video). Retrieved 21/01/2016 from http://www.ecpa.eu/tags/counterfeit-pesticides (1:55)

Europol \& The Office for Harmonization in the Internal Market (2012). Awareness Conference on Fake and Illicit Pesticides: Report and Conclusions. Retrieved 20/01/2016 from https://oami.europa.eu/tunnelweb/secure/webdav/guest/document library/observatory/documents/Knowledgebuilding-events/1392909557_pesticides_report_en.pdf

Extoxnet (1996). Aluminium Phosphide. Retrieved 21/01/2016 from http://pmep.cce.cornell.edu/profiles/extoxnet/24d-captan/aluminium-phosphide-ext.html

FAO (2014) Horizon Scanning and Foresight: An overview of approaches and possible applications in Food Safety. Retrieved 20/07/2017 from www.fao.org/3/a-i4061e.pdf.

Farmers Weekly (2015). Tougher metal theft penalties to benefit farmers. Retrieved 18/01/2016 from http://www.fwi.co.uk/news/tougher-metal-theft-penalties-to-benefitfarmers.htm

Farming UK (2014). Cost of rural crime revealed as Yorkshire sees most theft. Retrieved 18/01/2016 from http://www.farminguk.com/News/Cost-of-rural-crime-revealed-asYorkshire-sees-most-theft 30641.html

Galbraith, K. (2008). Solar Panels are Vanishing, Only to Reappear on the Internet. New York Times, September 23, 2008. Retrieved 25/03/2016 from http://www.nytimes.com/2008/09/24/technology/24solar.html

$\begin{array}{lllll}\text { Game } & \text { Act } & \text { (1831) } & \text { Retrieved } & \text { 09/03/2017 }\end{array}$ http://www.legislation.gov.uk/ukpga/Will4/1-2/32/contents 
Garnett, K., Lickorish, F.A., Rocks, S.A., Prpich, G., Rathe, A.A., Pollard, S.J.T. (2016) Integrating horizon scanning and strategic risk prioritisation using a weight of evidence framework to inform policy decisions. Science of the Total Environment, 560-561: 8291. DOI: 10.1016/j.scitotenv.2016.04.040.

Gaub, F. and Lisiecka, J. (2014) The crime-terrorism nexus. European Union Institute for Security Studies (EUISS), briefing 10, EUISS, Paris, France

Gilling, D. \& Pierpoint, H. (1999). Crime prevention in rural areas. In G. Dingwall \& S. Moody (Eds.) Crime and Conflict in the Countryside. Cardiff: University of Wales Press

Gov.uk (2018) Horizon Scanning. Retrieved 10/09/2018 from https:/www.gov.uk/government/groups/horizon-scanning-programme-team\#role

Hardy, E., Hooper, M., \& Griggs, S. (2007). Problem Profile: Vehicles Stolen for Export. Report by ACPO Vehicle Crime Intelligence Service. Retrieved 18/04/2016 from http://www.righttoride.org.uk/documents/AVCIS-Problem-Profile-Evaluation-of-

Vehicles-Stolen-for-Export unrestricted.pdf

Highways England (2015) A14 Cambridge to Huntingdon Improvement Scheme. Retrieved 08/03/2017 from https://infrastructure.planninginspectorate.gov.uk/wpcontent/ipc/uploads/projects/TR010018/TR010018-002254165\%20Statement $\% 20$ of $\% 20$ Common $\% 20$ Ground $\% 20$ Report.pdf

HM Government (2014). Modern Slavery Strategy. Retrieved 18/01/2016 from https://www.gov.uk/government/uploads/system/uploads/attachment_data/file/383764/ Modern Slavery Strategy FINAL DEC2015.pdf

HMIC (2017) PEEL: Police effectiveness 2016. Retrieved 03/03/2017 from https://www.justiceinspectorates.gov.uk/hmic/wp-content/uploads/peel-policeeffectiveness-2016.pdf

Hogg, R. \& Carrington, K. (2006). Policing the rural crisis. Sydney: Federation Press

House of Commons (2014) Government horizon scanning. London: Stationery Office.

Humberside Police (2015) Hare Coursing. Retrieved 09/03/2017 from http://www.humberside.police.uk/campaign/hare-coursing

$\begin{array}{lllll}\text { Hunting Act } & \text { (2004) } & \text { Retrieved } & \text { 13/03/2017 }\end{array}$ http://www.legislation.gov.uk/ukpga/2004/37/contents

Jobes, P.C. (2002). Effective officer and good neighbour: Problems and perceptions among police in rural Australia. Policing: An International Journal of Police Strategies and Management, 25; 256-273. DOI: 10.1108/13639510210429365. 
Lawson, J. (2012). The PV Industry Tackles Solar Theft. Retrieved 30/04/2016 from http:/www.renewableenergyworld.com/articles/print/special-supplement-large-scalesolar/volume-2/issue-1/solar-energy/the-pv-industry-tackles-solar-theft.html

Lincolnshire Police (2016) Hare Coursing. Retrieved 09/03/2017 from https://www.lincs.police.uk/get-help-advice/wildlife-and-rural-crime/hare-coursing/

Lincolnshire Police (2017) Team spirit traps hare coursers. Retrieved 09/03/2017 from https://www.lincs.police.uk/news-campaigns/news/2017/team-spirit-traps-harecoursers/

Local Government Association (2015). Tackling Serious and Organised Crime: a local response. London: Local Government Association

Loveday, B (2017) Still plodding along? The police response to the changing profile of crime in England and Wales. International Journal of Police Science \& Management, 19; 101-109. DOI: $10.1177 / 1461355717699634$.

Makarenko, T. and Mequita, M. (2014) Categorising the crime-terror nexus in the European Union. Journal of Global Crime, 15(3-4); 259-274. DOI: 10.1080/17440572.2014.931227.

Mawby, R.I. (2007). Myth and reality in rural policing: Perceptions of the police in a rural county. Policing: An International Journal of Police Strategies and Management, 27; 431-446. DOI: 10.1108/13639510410553158.

McAfee (2011). Prospective Analysis on Trends in Cybercrime from 2011 to 2020. Retrieved 19/04/2016 from http://www.mcafee.com/uk/resources/white-papers/wptrends-in-cybercrime-2011-2020.pdf

Ministry of Defence (2015). New signs on Salisbury Plain aim to protect precious environment. Retrieved 12/04/2016 from https://www.gov.uk/government/news/newsigns-on-salisbury-plain-aim-to-protect-precious-environment

Minnesota Department of Agriculture (Undated). Anhydrous Ammonia Theft. Retrieved 21/01/2016 from http://www.mda.state.mn.us/chemicals/spills/ammoniaspills/theft.aspx

Moore-Walsh, K. \& Walsh, L. (2017) Agricultural Crime in Ireland Report 1: Incidence of Agricultural Crime in Ireland. Waterford Institute of Technology. Retrieved 26/04/2017 from https://icsaireland.ie/wp-content/uploads/2017/03/ICSA-WITAgriculture-Crime-Survey-Report-1.pdf

Natural England (2008) A guide to definitive maps and changes to public rights of way 2008 Revision. $\quad$ Retrieved $07 / 03 / 2018$ from https:/www.gov.uk/government/uploads/system/uploads/attachment_data/file/414670/d efinitive-map-guide.pdf 
Natural Environment and Rural Communities Act (2006) Retrieved 08/03/2017 from http://www.legislation.gov.uk/ukpga/2006/16/section/40

Natural Resources Wales (2014). Illegal off-road driving damages Protected Sites. Retrieved 18/01/2016 from https://www.naturalresources.wales/about-us/news-andevents/news-releases/illegal-off-road-driving-damages-protected-sites/?lang=en

NFU Mutual (2015). Rural Crime 2015 - Secure Together. Retrieved 18/09/2015 from https://www.nfumutual.co.uk/farming/initiatives/rural-crime/

Night Poaching Act (1828) Retrieved 09/03/2017 from http://www.legislation.gov.uk/ukpga/Geo4/9/69/contents

OECD (2018) Schooling for Tomorrow knowledge base. Retrieved 10/09/2018 from https://www.oecd.org/site/schoolingfortomorrowknowledgebase/futuresthinking/overvie wofmethodologies.htm

Plymouth Herald (2016). Villages go 'feral' as police cuts 'abandon' countryside to rural crime wave. Retrieved 20/04/2016 from http://www.plymouthherald.co.uk/Villagesferal-police-cuts-leave-countryside/story-29110656-detail/story.html

Price, V., Sidebottom, A. \& Tilley, N. (2014). Understanding and Preventing Lead Theft from Churches: A Script Analysis. In L. Grove, S. Thomas (Eds.) Heritage Crime: progress, prospects and prevention. London: Palgrave MacMillan

Quinn, T. (2015). Shooting's strangest days: Extraordinary but true stories from 200 years of shooting. London: Portico

Rehman, A., Jingdong, L., Khatoon, R. \& Hussain, I. (2016) Modern Agricultural Technology Adoption its Importance, Role and Usage for the Improvement of Agriculture. American-Eurasion Journal of Agricultural \& Environmental Science, 16; 284-288. DOI: 10.5829/idosi.aejaes.2016.16.2.12840

Rentokil (Undated). Phostoxin for Mole, Rabbit and Rat Control. Retrieved 21/01/2016 from http://www.rentokil.co.uk/technical-expertise/phostoxin/

Rights of Way Act (1990) Retrieved 08/03/2017 from http:/www.legislation.gov.uk/ukpga/1990/24/contents

Road Traffic Act (1988) Retrieved 09/03/2017 from http://www.legislation.gov.uk/ukpga/1988/52/contents

RSM UK (2015). Fraud and cybercrime committed every four seconds in the UK cybercrime now deemed more common than traditional crime. Retrieved 19/04/2016 from https://www.rsmuk.com/ideas-and-insights/fraud-and-cybercrime-committedevery-four-seconds-in-the-uk 
Sambrook, C (2013) UK agriculture should acknowledge threat of counterfeit pesticides. Retrieved 13/03/2017 from http://www.harper-adams.ac.uk/news/202020/ukagriculture-should-acknowledge-threat-of-counterfeit-pesticides\#.WMaUo2-LS70

Scrap Metal Dealers Act (2013) Retrieved 21/02/2017 from http://www.legislation.gov.uk/ukpga/2013/10/contents/enacted

Sentencing Council (2015a). Theft Offences: Definitive Guideline. Retrieved 18/01/2016 from https://www.sentencingcouncil.org.uk/publications/item/theft-offences-definitiveguideline/

Sentencing Council (2015b). Theft Offences: new sentencing guidelines announced. Retrieved 18/01/2016 from https://www.sentencingcouncil.org.uk/news/item/theftoffences-new-sentencing-guidelines-announced/

Smith, K. \& Byrne, R. (2017) Farm Crime in England and Wales: A Preliminary Scoping Study Examining Farmer Attitudes. International Journal of Rural Criminology, 3; 191223. DOI: $10.18061 / 1811 / 81047$.

Smith, R. (2010) Policing the changing landscape of rural crime: a case study from Scotland. International Journal of Police Science and Management, 12; 373-387. DOI: 10.1350/ijps.2010.12.3.171.

Smith, R. \& McElwee, G. (2015). Developing qualitative research streams relating to illegal rural enterprise. International Journal of Entrepreneurial Behavior \& Research, 21; 364-388. DOI: 10.1108/IJEBR-01-2014-0019

Stratford-upon-Avon Herald (2017) Police investigate solar panel theft. Retrieved 24/10/2017 from http://www.stratford-herald.com/75674-police-investigate-solar-paneltheft.html

Sutherland, W.J., Clout, M., Cote, I.M. et al (2010) A horizon scan of global conservation issues for 2010. Trends in Ecology and Evolution, 25: 1-7. DOI: 10.1016/j.tree.2009.10.003.

Sutherland, W.J., Barnard, P., Broad, S. et al (2017) A 2017 Horizon Scan of Emerging Issues for Global Conservation and Biological Diversity. Trends in Ecology and Evolution, 32: 31-40. DOI: 10.1016/j.tree.2016.11.005.

Telegraph (2015). Stone theft hits 'epidemic' levels. Retrieved 26/04/2016 from http:/www.telegraph.co.uk/news/uknews/crime/11694827/Stone-theft-hits-epidemiclevels.html

The Deer Initiative (2017) Project Poacher. Retrieved 09/03/2017 from http://www.thedeerinitiative.co.uk/news/record.php?id=193 
The Guardian (2014) UK solar farm subsidies to be cut. Retrieved 13/10/2017 from https://www.theguardian.com/environment/2014/apr/30/uk-solar-farm-subsidies-cutpanels-buildings

The Independent (2015) Sophisticated gangs using drones to target church roofs for their lead. $\quad$ Retrieved 20/04/2016 from http://www.independent.co.uk/news/uk/crime/sophisticated-gangs-using-drones-totarget-church-foofs-for-their-lead-a6688611.html

The Times (2015). Flying 'sheepdog' is proving to be the farmer's best friend. Retrieved 26/04/2016 from http://www.thetimes.co.uk/tto/technology/article4401959.ece

$\begin{array}{lllll}\text { Theft } & \text { Act } & \text { (1968) } & \text { Retrieved } & \text { 09/03/2017 }\end{array}$ http://www.legislation.gov.uk/ukpga/1968/60/contents

Torres-Sanchez, J., Lopez-Granados, F., De Castron, A.I., \& Pena-Barragan, J.M. (2013). Configuration and Specifications of an Unmanned Aerial Vehicle (UAV) for Early Site Specific Weed Management. PLOS One, 8; e58210. DOI: 10.1371/journal.pone.0058210

Wall, D.S. \& Chistyakova, Y. (2015). Organised Crime in the UK: The Organised Crime Portfolio Research Project. ECPR Standing Group on Organised Crime Newsletter, 12, May 2015. $\quad$ Retrieved 24/04/2016 from http://sgocnet.org/site/wpcontent/uploads/2014/05/May20151.pdf

Weisheit, R.A., Falcone, D.N., \& Wells, L.E. (2005). Crime and Policing in Rural and Small-Town America (3rd Ed.). Long Grove, IL: Waveland Press

Wildlife and Countryside Act (1981) Retrieved 09/03/2017 from http://www.legislation.gov.uk/ukpga/1981/69

Wiles, P. \& Costello, A. (2000). The 'road to nowhere': The evidence for travelling criminals. London: Home Office Research, Development and Statistics Directorate

Yarwood, R. (2001). Crime and policing in the British countryside: Some agendas for contemporary geographical research. Sociologia Ruralis, 41; 201-221. DOI: 10.1111/1467-9523.00178. 